\title{
Some influences of zero-tillage on the structure and stability of a fine-textured river levee soil
}

\author{
F. R. Boone ${ }^{1}$, S. Slager ${ }^{2}$, R. Miedema² and R. Eleveld ${ }^{2}$
}

1 Soil Tillage Laboratory, Agricultural University, Diedenweg 20, Wageningen, the Netherlands

${ }^{2}$ Department of Soil Science and Geology, Agricultural University, P.O. Box 37, Wageningen, the Netherlands

Accepted: 15 January 1976

Key words: zero-tillage, soil micromorphology, fluviatile deposit

\section{Summary}

By means of a number of physical and micromorphological analyses the difference in soil structure between ploughing and 5 years zero-tillage on a fine-textured fluviatile deposit is characterized. Although bigger pores are less stable and consequently more easily affected by compaction it appears that within each pore size class stability varies widely. Zero-tillage results in a more dense and more homogeneous soil in which small aggregates disappear and aggregate stability increases, whereas pore continuity is not improved very much.

Active pseudogleying is responsible for extensive bleaching in the zero-tillage profile, caused by a periodical lack of oxygen.

The earthworm population increased markedly, but most earthworms were small. The number of large worm holes decreases sharply with depth which is an indication for a poor environment for the deep-burrowing worms which improve vertical water transport.

Temporary pool formation is observed on part of the zero-tillage plots in the autumn and winter of the last few years and even after a heavy rainstorm in June 1975. At the last event many worms died on the zero-tillage plots.

For conditions prevailing in the Netherlands there seem to be at least two soil texture ranges that are less suited for zero-tillage: on (loamy) sandy soils with a relatively low organic matter content zero-tillage is unsuccessful for root crops, and on fine-textured soils insecurities are introduced especially for crops sown in autumn.

\section{Introduction}

Soil tillage may be carried out for several reasons. First of all, it is an essential part of the crop production technique characterized by its mechanization level. In tempe- 
rate regions the main function of potato ridges, for instance, is to facilitate mechanized harvesting whereas for sowing a loose topsoil has considerable technical advantages over a compact untilled soil. Secondly, tillage is an effective method of weed control. One of the important conclusions of recent research in zero-tillage (Bakermans et al., 1974) is that the present application of herbicides depends on the prevention of weeds by tillage operations. In the third place tillage may improve soil structure in such a way that risks for yield depressions are significantly diminished (Boone, 1976). Finally, soil tillage solves some waste disposal problems improving, for instance, destruction of organic substances like liquid manure and crop residues by micro-organisms.

Characterization of changes in soil structure and their consequences that result from omitting tillage is far from complete even in a qualitative sense. The present study deals with a comparison of ploughed and zero-tillage plots from an experiment on a fine-textured holocene fluviatile deposit. The difference in structure which resulted from a difference in soil management during 5 years or more is characterized by means of a number of physical and micromorphological analyses.

\section{Materials and methods}

The experimental farm of the Institute for Biological and Chemical Research on Field Crops and Herbage (IBS) situated near Randwijk, Betuwe District, is located on the transition from a levee of the river Rhine to the adjacent river basin. Three years before the experiment started there, grass was sown on a plot of land which was used for a long time for arable farming. Since 1968 one third of the experimental field was ploughed in a traditional way, one third was spaded with a spading machine, and one third was not tilled any more.

In the last case sowing was performed by an adapted sowing machine (Bakermans, 1970), and weed was controlled by herbicides. There was no fixed crop rotation. Six different crops were grown side by side but most observations refer to plots under maize. Most of the areas studied were chosen as near as possible to each other to avoid possible differences in soil texture.

Soil structure descriptions were made in the field according to the Soil Survey Manual (Anon., 1961). At several spots the number of small worm holes ( $\varnothing 2-4 \mathrm{~mm}$ ) and the number of large worm holes $(\varnothing>4 \mathrm{~mm})$ at different depths were counted on an area of $500 \mathrm{~cm}^{2}$ in October 1975 (Slager, 1966).

Soil physical analyses (10 replications) included the determination of the soil-waterair ratio and the $\mathrm{pF}$ curve of undisturbed core samples $\left(100 \mathrm{~cm}^{3}\right)$ taken before maize harvest in October 1973 from a depth of 2-7, 12-17 and 27-32 cm. For suctions up to $\mathrm{pF} 2.0$ a sandbox and for higher suctions a pressure membrane apparatus was used. In addition, undisturbed core samples from $0-5$ and $5-10 \mathrm{~cm}$ were taken for air permeability measurements in June 1975 . In June 1974 the air permeability and the oxygen diffusion coefficient were determined in undisturbed core samples $\left(250 \mathrm{~cm}^{3}\right)$ from a depth of $3-8 \mathrm{~cm}$ of the tilled plot and from $12-17 \mathrm{~cm}$ of a plot close to the main experimental field which was not tilled since 1964 . The air perme- 


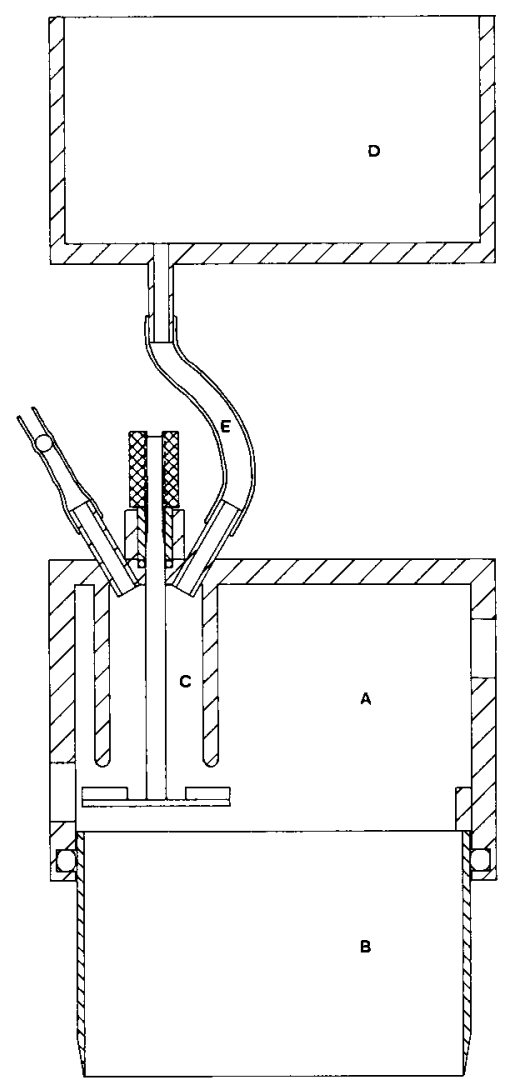

Fig. 1. Device for the measurement of the oxygen diffusion coefficient in soil cores. $\mathrm{A}=$ cap filled with oxygen; $\mathrm{B}=$ soil core; $\mathrm{C}=$ one of three compartments; $\mathrm{D}=$ container with water; $\mathrm{E}=$ tube to be closed with tubing clamp.

ability was measured according to Kmoch (1961), the oxygen diffusion coefficient by a modification (Fig. 1) of the procedure used by Bakker \& Hidding (1970). After filling the cap with oxygen, the small compartments within the cap are closed at time $t_{1}, t_{2}$ and $t_{3}$, respectively. Oxygen concentration in these compartments are determined afterwards with a membrane covered electrode from a polarographic oxygen analyser by replacing the gas in the compartments by water. With these devices a large number of samples can be handled in a short time.

For aggregate stability determinations soil material was collected from a depth of $0-5,12-17$ and $27-32 \mathrm{~cm}$, oven-dried $\left(30^{\circ} \mathrm{C}\right)$ and slightly crushed by dry sieving (October 1973). The same procedure was followed for soil material that was puddled by hand. 100 aggregates (4.5-4.8 mm diameter), saturated in vacuum, were spread on a rotating sieve with openings of $4 \mathrm{~mm}$ and exposed to a heavy artificial rainfall with rain-drops of $80-100 \mathrm{mg}$.

In order to promote fragmentation undisturbed soil cores from a depth of $12-17 \mathrm{~cm}$ with a water content of $22.5 \%(\mathrm{w} / \mathrm{w})$ were stored for 12 hours at $-25^{\circ} \mathrm{C}$ (October 1973). After thawing the samples were placed under water on top of a set 
Table 1. The granulometry (\%) of the ploughed and untilled area (depth $12-17 \mathrm{~cm}$ ).

\begin{tabular}{lcc}
\hline Fraction & Ploughed & Untilled \\
$>50 \mu \mathrm{m}$ & 8.0 & \\
$50-16 \mu \mathrm{m}$ & 30.7 & 3.3 \\
$16-2 \mu \mathrm{m}$ & 25.4 & 26.1 \\
$<2 \mu \mathrm{m}$ & 35.9 & 36.6 \\
\hline
\end{tabular}

of sieves which were shaken gently by hand. The weight percentage of the original sample which remained in each sieve was determined.

Micromorphological analyses. The plots were sampled between 0 and $32 \mathrm{~cm}$ below the soil surface with sample boxes $(5 \times 8 \times 15 \mathrm{~cm})$ in the spring before maize was sown and in the autumn before maize harvest (March and October 1973). Thin sections (size $8 \times 15 \mathrm{~cm}$ ) have been prepared with a method which enables to fixate the soil at field moisture content without shrinking during sample preparation (Miedema et al., 1974).

A qualitative description followed, with the terminology of Brewer (1964), in order to detect differences between the two soils under consideration.

A point-counting technique was used to estimate the surface areas in the thin sections which were enriched or impoverished in ferric compounds due to iron segregation (March 1973). At each depth interval about 800 points were counted.

The pore-size frequency distribution was determined by means of a line counting at several depths in the spring and autumn samples of the two soils.

\section{Results}

Soil structure description and physical analyses

The granulometry of the $12-17 \mathrm{~cm}$ layer shows few or no differences between the main sampled areas (Table 1).

The main difference in the soil structure is the presence of granular elements near the soil surface $(0-2 \mathrm{~cm})$, a weakly developed platy structure between $2-4 \mathrm{~cm}$ (Fig. 2) and somewhat larger aggregates between 4 and $30 \mathrm{~cm}$ on the zero-tillage

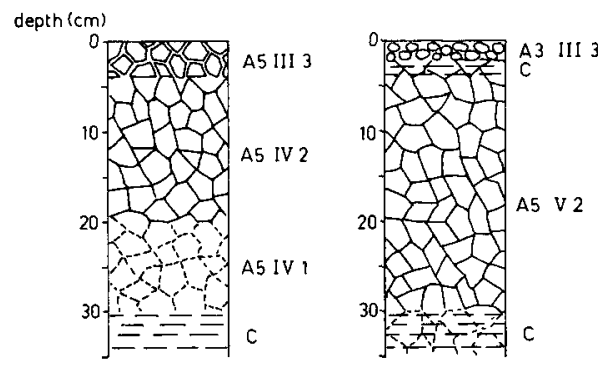

Fig. 2. Soil structure descriptions of the ploughed area (left) and untilled area (right). Ploughed plot: $0-4 \mathrm{~cm}$ : strong, very fine, angular blocky; 4-20 $\mathrm{cm}$; moderate, fine, angular blocky; 20-30 $\mathrm{cm}$ : weak, fine, angular blocky; $30-35 \mathrm{~cm}$ : moderate, medium, platy. Zero-tillage plot: $0-2$ $\mathrm{cm}$ : strong, very fine, granular; $2-4 \mathrm{~cm}$ : moderate, thin, platy; $4-30 \mathrm{~cm}$ : moderate, medium, angular blocky; $30-35 \mathrm{~cm}$ : weak, medium, platy. 
ZERO-TILLAGE ON A RIVER LEVEE SOIL

Table 2. The organic matter content $(\%)$ of different layers of the ploughed and untilled area.

\begin{tabular}{rll}
\hline Depth $(\mathrm{cm})$ & Ploughed & Untilled \\
$0-5$ & 2.18 & 3.02 \\
$12-17$ & 2.10 & 1.47 \\
$27-32$ & 1.21 & 1.00 \\
\hline
\end{tabular}

plots. A plough pan could be detected in the two profiles of the ploughed plot studied, but was not clearly visible in one of the two studied zero-tillage profiles.

Further information about the structures under consideration is presented in Tables 2 and 3. As aspected (van Ouwerkerk \& Boone, 1970; Fleige, 1974) the organic matter content in the $0-5$ layer of the zero-tillage plot is clearly higher but in the $12-17 \mathrm{~cm}$ layer lower and in the $27-32 \mathrm{~cm}$ layer somewhat lower than in the ploughed plot. Without the loosening and mixing action of the plough, organic matter accumulates in the topsoil and diminishes at greater depths. Pore volume decreases by omitting soil tillage especially in the lower part of the formerly ploughed layer. The $27-32 \mathrm{~cm}$ layer of the sampled spot, however, had a higher pore volume, which will be explained later. The standard deviation of the single value decreases under zero-tillage which means that soil structure homogeneity increases (van Ouwerkerk \& Boone, 1970). As a consequence of the lower pore volume, air content at pF 2.0 decreases but to a smaller extent than could be expected from the decrease in pore volume. Beyond a certain point pore volume is too low to contain the same quantity of water as is found at high pore volume. Therefore soil water content at $\mathrm{pF} 2.0$ is positively correlated with pore volume in a very dense soil (Kuipers, 1961). This severe compaction is only possible when it takes place at water contents below pF 2.0.

The different structures found in the tilled and untilled soil are strongly influenced by and partly arise from soil tillage and subsequent compaction. As a consequence $\mathrm{pF}$ values of the lower suction range of different pore volumes give information about which pore sizes are most affected when a loose soil is compacted. Starting

Table 3. Pore volume, water content at $\mathrm{pF} 2.0$ and air content at $\mathrm{pF} 2.0 .1=$ ploughed area; $2=$ untilled area.

\begin{tabular}{|c|c|c|c|c|c|c|c|c|}
\hline \multirow{3}{*}{$\begin{array}{l}\text { Depth } \\
(\mathrm{cm})\end{array}$} & \multicolumn{4}{|c|}{ Pore volume } & \multirow{2}{*}{\multicolumn{2}{|c|}{$\begin{array}{l}\text { Water content } \\
\text { at pF } 2.0 \\
(\% \mathrm{w} / \mathrm{w})\end{array}$}} & \multirow{2}{*}{\multicolumn{2}{|c|}{$\begin{array}{l}\text { Air content } \\
\text { at } \mathrm{pF} 2.0 \\
(\% \mathrm{v} / \mathrm{v})\end{array}$}} \\
\hline & \multicolumn{2}{|c|}{ mean } & \multicolumn{2}{|c|}{$\begin{array}{l}\text { standard deviation } \\
\text { of the single value }\end{array}$} & & & & \\
\hline & 1 & 2 & 1 & 2 & 1 & 2 & 1 & 2 \\
\hline $2-7$ & 46.6 & 45.9 & 3.2 & 0.7 & 25.5 & 26.3 & 10.0 & 7.7 \\
\hline $12-17$ & 45.1 & 42.3 & 1.6 & 1.0 & 25.2 & 23.6 & 7.9 & 5.8 \\
\hline $27-32$ & 42.2 & 45.2 & 1.2 & 1.0 & 22.8 & 26.4 & 6.8 & 5.3 \\
\hline
\end{tabular}




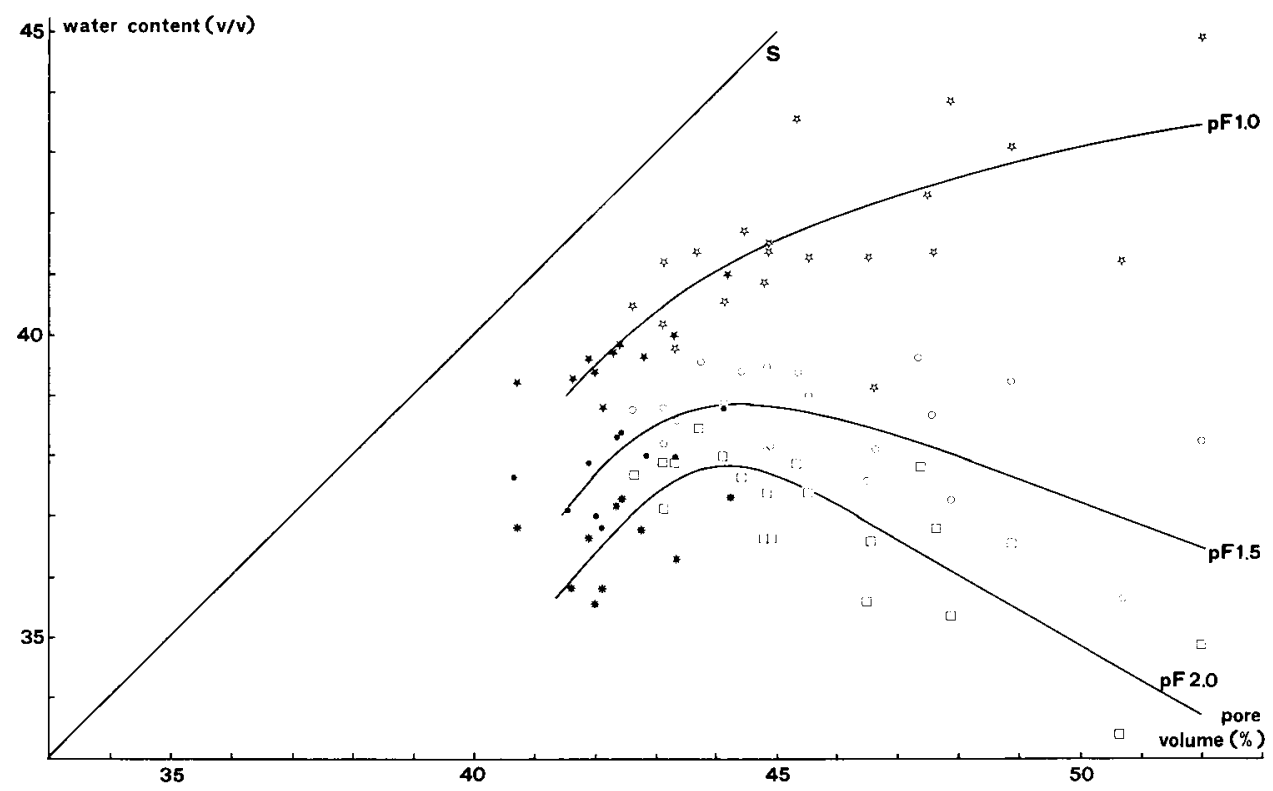

Fig. 3. Water content (v/v) at $\mathrm{pF} 1.0$ (stars), $\mathrm{pF} 1.5$ (dots) and $\mathrm{pF} 2.0$ (squares and asterisks) of undisturbed core samples of the ploughed (open symbols; depth 2-7 and 12-17 cm) and untilled plot (black symbols; depth $12-17 \mathrm{~cm})$ in relation to pore volume $(\mathrm{S}=$ saturation line).

from a high pore volume it appears that, in the first stage of compaction (pore volume $>50 \%$ ), in particular pores with an (equivalent) diameter of $>300 \mu \mathrm{m}$ ( $\mathrm{pF}<1.0$ ) disappear (Fig. 3). Pores with a diameter of $100-300 \mu \mathrm{m}(\mathrm{pF} 1.5-1.0)$ are affected at the same time but to a lower extent. They disappear especially in later stages of compaction. The number of pores between 30 and $100 \mu \mathrm{m}$ (pF $2.0-$ $\mathrm{pF}$ 1.5), however, is relatively unaffected in all stages of compaction. At the same time the number of pores smaller than $30 \mu \mathrm{m}$ in a certain volume increases up to a critical point already mentioned by Kuipers (1968). These pores are nearly unaffected (the smaller they are the more unaffected) by compaction whereas the larger pores are replaced by soil material with small(er) pores. In general the big pores are easily deformed, the fine pores are more stable. Within each pore-size class, however, stability varies to a great extent which can be concluded from the fact that compaction disturbs pores of different sizes at the same time.

Besides by the amount of pores of different pore size classes, soil structure can be characterized by the three-dimensional arrangement of the larger pores, and the continuity of the pore system.

About the three-dimensional arrangement of the aggregates and the larger pores between them the wet-aggregate analysis provides for some interesting information (Fig. 4). Under zero-tillage the size of the aggregates is considerably larger, whereas the aggregate size distribution is more homogeneous. Especially the small aggregates 

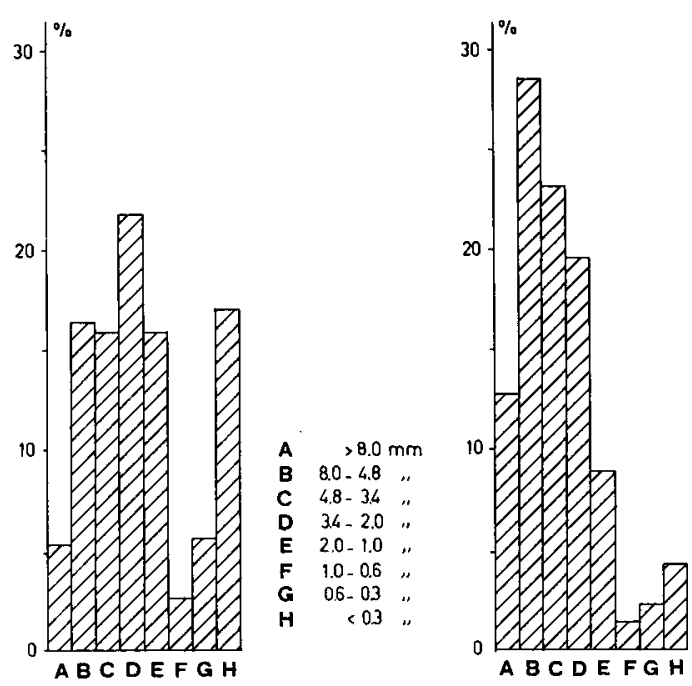

Fig. 4. Results of the wet-aggregate analysis. The amount of different aggregate sizes $(\mathrm{mm})$ is given for the ploughed (left) and untilled plot (right) as a percentage of total weight.

with a diameter smaller than $0.3 \mathrm{~mm}$ disappear. A pore system with a relatively high air content can have a worse continuity than a system with a lower air content. It is possible that continuity has to be built up in time and therefore a small plot close to the main experimental field which was not tilled for 10 years was sampled and compared with a normally tilled plot. It turns out that the gas diffusion coefficient $\left(D_{s}\right)$ rises very steeply with the air content, as can be expected from a finetextured soil with blocky structure elements (Fig. 5). At the same air content the untilled soil has a somewhat higher gas diffusion coefficient than the ploughed soil. However, the differences in structure within each soil are much larger than between them. The gas diffusion coefficient changes with a factor ten or more from one spot to another.

We can hypothese that aggregates persist longer under zero-tillage than in a ploughed soil because ploughing and seed-bed preparation allways destroy and deform aggregates to a certain extent. In the second place, the difference in displacement between two neighbouring soil particles can be larger by the compacting and smearing action of wheels in a loosened soil than in an already compacted soil. Aggregates from untilled soil with a diameter of $4.5-4.8 \mathrm{~mm}$ are indeed more stable against rain-drop impact (Table 4). Artificial aggregates from a puddled soil are weaker than from a ploughed soil. Seed-bed preparation on the ploughed soil was the last disturbing action. Aggregates from shallow layers of ploughed plots are therefore compared with aggregates from the deepest sampled layer that has been untouched for a relatively long time. It appears that the aggregates tend to become more stable the longer the soil remained untouched. The steep increase in stability of aggregates from puddled soil with depth, however, can not be explained from the available figures. 


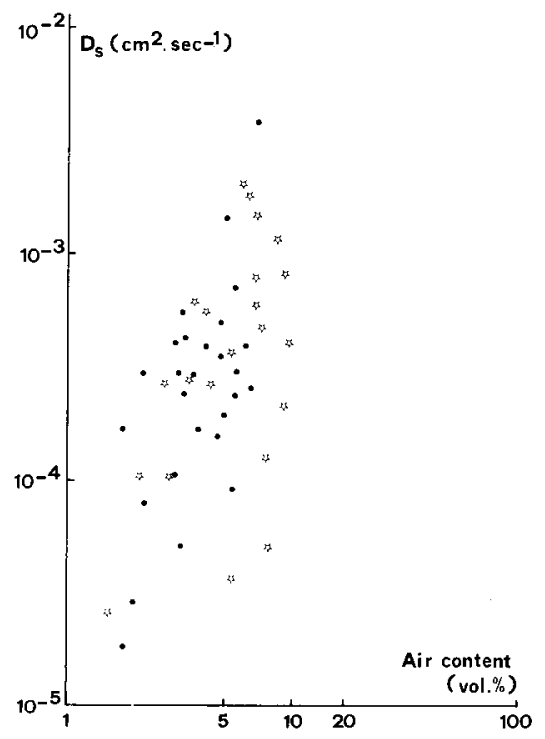

Fig. 5. The gas diffusion coefficient of undisturbed soil cores from the ploughed plot (stars; depth 3-8 $\mathrm{cm}$ ) and untilled plot (dots: depth $12-17 \mathrm{~cm}$ ) in relation to air content $(\% \mathrm{v} / \mathrm{v})$.

\section{Micromorphology}

The ground mass of all samples studied consists of a mixture of skeleton grains and plasma. The skeleton grains mainly occur in a random distribution pattern. Clusters of skeleton grains form a striking feature near the soil surface of all samples. In the ploughed soil also some distinct banded distribution patterns of skeleton grains were observed. The plasma consists of a mixture of clay minerals, ferric compounds and organic matter. The plasma is in some places poor in ferric compounds, especially in the zero-tillage soil. The plasmic fabric is mainly asepic with some vague plasma reorientations.

The spring samples of the ploughed soil contain many vughs and interconnected vughs (Fig. 6) and relatively few channels and craze planes. The autumn samples of

Table 4. Pore volume and aggregate stability of aggregates with a diameter of $4.5-4.8 \mathrm{~mm}$ against rain-drop impact characterized by their half-life in seconds.

\begin{tabular}{|c|c|c|c|c|c|c|}
\hline \multirow{2}{*}{$\begin{array}{l}\text { Depth } \\
(\mathrm{cm})\end{array}$} & \multicolumn{2}{|c|}{ Ploughed } & \multicolumn{2}{|l|}{ Untilled } & \multicolumn{2}{|l|}{ Puddled } \\
\hline & $\begin{array}{l}\text { pore } \\
\text { volume } \\
(\%)\end{array}$ & $\begin{array}{l}\text { aggregate } \\
\text { stability } \\
\text { (s) }\end{array}$ & $\begin{array}{l}\text { pore } \\
\text { volume } \\
(\%)\end{array}$ & $\begin{array}{l}\text { aggregate } \\
\text { stability } \\
\text { (s) }\end{array}$ & $\begin{array}{l}\text { pore } \\
\text { volume } \\
(\%)\end{array}$ & $\begin{array}{l}\text { aggregate } \\
\text { stability } \\
\text { (s) }\end{array}$ \\
\hline $0-5$ & 33.9 & 36 & 34.3 & 84 & 39.8 & 22 \\
\hline $12-17$ & 31.2 & 76 & 30.8 & 100 & 35.1 & 40 \\
\hline $27-32$ & 31.0 & 156 & 32.6 & 180 & 32.4 & 108 \\
\hline
\end{tabular}




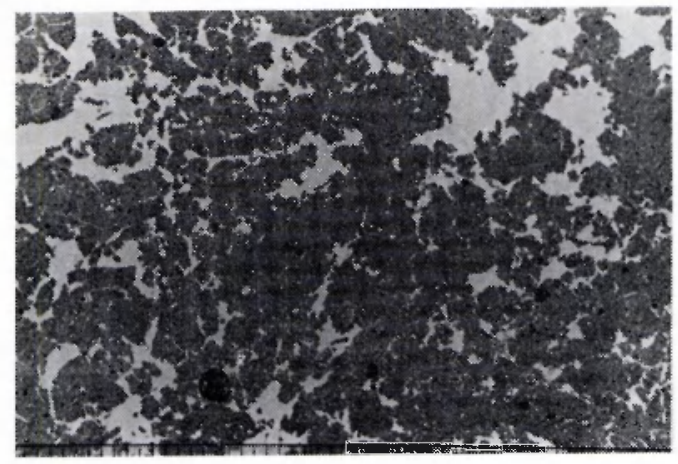

Fig. 6. Thin section of the top of the ploughed soil in the spring, displaying many vughs and interconnected vughs, but relatively few channels and craze planes $(\times 0.4$; ordinary light).

the ploughed soil contain a distinctly lower number of vughs and interconnected vughs than the spring samples but somewhat more craze planes (Fig. 7). The number of channels is about the same in the spring and autumn samples of the ploughed soil. The difference in pore size frequency is mainly due to a difference in abundance of the pores $>100 \mu \mathrm{m}$. Pores $>500 \mu \mathrm{m}$ are rare to absent in the autumn sample.

The samples of the zero-tillage soil display quite another picture. Both spring and autumn samples contain few vughs, interconnected vughs and channels, whereas craze planes occur regularly. The zero-tillage soil has more pores $<100 \mu \mathrm{m}$ than the ploughed soil. Judged from their shape somewhat more pores in the zero-tillage soil are biogenic from origin than in the ploughed soil. The number of large pores in the zero-tillage soil, however, is very small even in comparison to the autumn sample of the ploughed soil. (Organo)-matri-ferriargillans (van Schuylenborgh et al., 1970) were found below $25 \mathrm{~cm}$ in both zero-tillage samples and one sample of the ploughed soil. They occur on the walls of channels and vughs and have a thickness ranging from 20 to $50 \mu \mathrm{m}$. Their abundance amounts up to $5.5 \%$ of the surface area of the thin sections with negligible differences between the two soils. In the autumn sample of the ploughed soil they were absent. In the upper $25 \mathrm{~cm}$ of both soils some small ferric nodules were observed. They are generally sharply bounded,

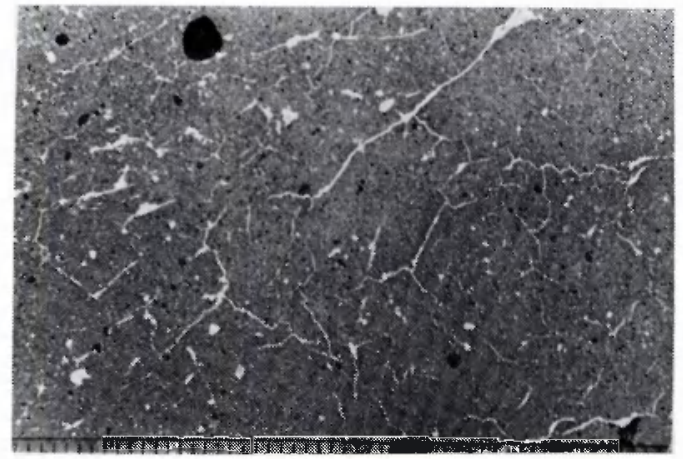

Neth. J. agric. Sci. 24 (1976)
Fig. 7. Thin section of the top of the ploughed soil in the autumn, displaying more craze planes, but less biogenic voids $(\times 0.4$; ordinary light $)$. 

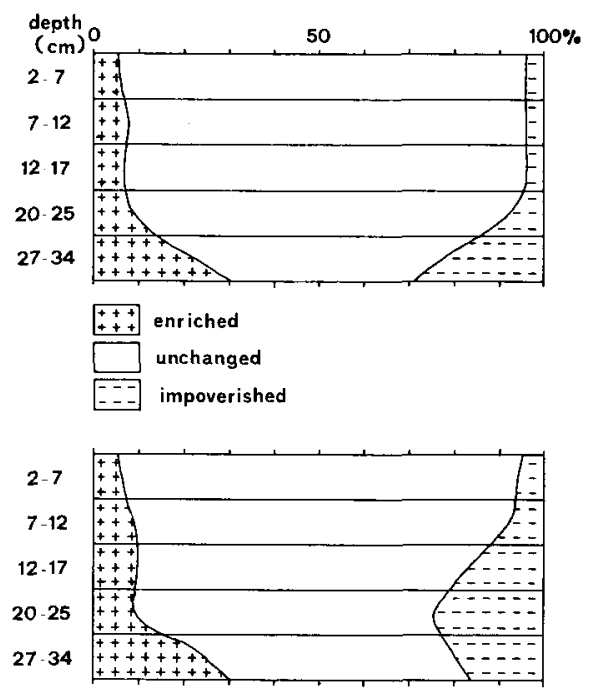

Fig. 8. Percentage of area of the ploughed (top) and untilled soil (bottom) which is enriched, unchanged or impoverished in ferric compounds as determined by point countings on thin sections.

but some diffusely bounded ones also occur, especially in the zero-tillage soil. Below $25 \mathrm{~cm}$ many ferric nodules occur in the zero-tillage samples and in the spring sample of the ploughed soil. Some of these nodules are sharply bounded, others have diffuse boundaries. They have sizes up to $1 \mathrm{~mm}$ and more.

From the reliability chart of van der Plas \& Tobi (1965) significantly larger bleached areas can be ascertained in the samples of the zero-tillage soil between 12 and $25 \mathrm{~cm}$ below the soil surface (Fig. 8). Moreover, in this soil the bleached area increased with depth, whereas it remained constant with depth in the ploughed soil. The areas enriched in iron compounds have about the same size in the two samples and remain relatively constant in size with depth.

Remnants of slaking crusts (Bouma, 1969) were found in both soils down to about $25 \mathrm{~cm}$. Their length may amount up to $1 \mathrm{~cm}$, their thickness up to $200 \mu \mathrm{m}$. They consist of an alternation of coarser and finer mineral grains (generally fine silt and coarse clay). Their distribution is random to clustered and they do not show any specific orientation towards the soil surface. These slaking crusts are found in the autumn sample of the ploughed soil up to $35 \mathrm{~cm}$ depth.

\section{Interpretation and discussion}

From the absence of matri-ferriargillans, the much smaller abundance of ferric nodules and the presence of remnants of slaking crusts in the soil below $25 \mathrm{~cm}$ from the autumn samples of the ploughed plot the conclusion can be drawn that on that spot the soil had been tilled deeper previously. The absence of a platy structure and the relatively high pore volume at plough pan depth in the zero-tillage soil is another indication of differences in soil management in the past. Interpretation will largely be restricted to observations obtained from the upper $25 \mathrm{~cm}$ because these layers 
seem fully comparable (see granulometry, ground-mass, abundance of matri-ferriargillans).

Changes of soil structure and related features comparing ploughed and untilled soil are manyfold as was shown, for instance, indirectly by differences in $\mathrm{pF}$ curves (Fig. 3) and directly by micromorphological observations (Fig. 6 and 7). Large (physicogenic) pores are created in a ploughed soil which for a part disappear by settling of the soil and for another part are destroyed later on by wheel action. The bigger and weaker the pores, the easier they are destroyed. Although smaller pores are stronger than big ones the simultaneous destruction of pores of different sizes indicates a large variation in resistance between pores of the same size. The way in which these pores are formed and the decrease in volume and number of these pores by compaction means that the soil structure is becoming more homogeneous under zero-tillage. This is especially true for the lower part of the plough layer (van Ouwerkerk \& Boone, 1970).

At the time of sampling, 5 years after the start of the experiment, almost all the unaggregated material had disappeared and the proportion of large aggregates was considerably higher (Fig. 4). Aggregates of the fraction $4.5-4.8 \mathrm{~mm}$ were more stable against rain-drop impact the longer they were untouched and the longer the forces of coherence could be built up.

The occurrence of clusters of skeleton grains near the top of the soil, of the banded distribution pattern of skeleton grains, of remnants of slaking crusts and of (organo)matri-ferriargillans reflect a complex process.

If rain falls on the unprotected soil surface a more or less intense shifting of the soil material into its components takes place. If the soil surface is relatively impermeable after prolonged rainfall, water pools arise in which the coarser components settle first and the finer components later, and a slaking crust is the result (Bouma, 1969; Jongerius, 1970). On ploughing the crust will be mixed through the plough layer, but will not fully desintegrate. If the soil surface allows for a downward transport of water, the finer components (clay, fine silt and possibly organic matter) will be transported in suspension to greater depth than the sand and silt grains, which remain at or near the soil surface. The finer components produce matri-ferriargillans, the coarser components clusters or bands of skeleton grains. From the observation that the amount of matri-ferriargillans is equal in the zerotillage and ploughed soil it could be ascertained whether the formation of these cutans has proceeded under zero-tillage. It is clear however, that the formation of a measurable amount of matri-ferriargillans takes much more time than the observation period of 5 years. Otherwise matri-ferriargillans would also have been found in the autumn sample of the ploughed soil.

The lower air content under zero-tillage and the increase in diameter of aggregates has its consequences for aeration. Although the variation is very large the gas diffusion coefficient increases very sharply with air content (Fig. 5) for both structures. At the same air content the untilled soil has a somewhat higher gas diffusion coefficient than the ploughed soil. When the gas diffusion coefficient at the same $\mathrm{pF}$ tension is compared, however, it turns out that pore continuity is not really improved. Increasing diameter of aggregates increases the chances for anaerobiosis 
in the centre of the aggregates which could be detected by micromorphology (Fig. 8). From the micromorphology of the iron segregation and from the field observation that the water table rarely arises up till ploughing depth, it can be concluded that the iron segregation results from either a fossile gleying or an active pseudogleying or both. The field observation of periodical pool formation on the zerotillage plot points to an active pseudogleying as one of the factors involved. The presence of sharply bounded ferric nodules in the upper $25 \mathrm{~cm}$ and the strong increase in their abundance below that depth pleads for fossil gley as the second factor. If it is assumed that both plots had the same history, it can be concluded that active pseudogleying is responsible for the extensive bleaching in the zero-tillage profile. The bleaching is caused by mobilization of iron compounds under reductive conditions in the presence of organic matter. It is a result of periodical lack of oxygen. Main causes for the less extensive bleaching in the ploughed top soil are the production of large pores every year on the one hand and the mixing by ploughing of the bleached and iron-bearing ground-mass on the other.

Under zero-tillage the soil structure can be improved only by swelling/shrinking processes and by biogenic factors with a phytogenic (plant roots) or zoogenic (worms) origin. In the last case it is important to know to which degree plant remnants accumulate at the soil surface and superficial soil layers are mixed into the soil. The total amount of organic matter increases slowly and is therefore not easily detectable under zero-tillage (Fleige, 1974), but a decrease of organic matter in the lower part of the formerly ploughed layer is easily observable, which means that soil animals cannot compete with ploughing in mixing action. Still the number of earthworms increased with a factor 3 after a few years of zero-tillage (Bakermans, 1972), which is in agreement with literature (Baeumer \& Bakermans, 1973). Instead of 90 worms $/ \mathrm{m}^{2}(0-30 \mathrm{~cm})$ about 270 worms $/ \mathrm{m}^{2}$ were counted, which can be considered a relatively high number; however most worms were small. Lumbricus terrestris, which is responsible for large and deep vertical channels essential for a fast and easy intake of water (Ehlers, 1975), was only sporadically observed. This is in agreement with the number of worm holes counted (Table 5). The number of small worm holes stayed nearly constant in the formerly ploughed layer but the number of large worm holes decreased sharply with depth. This may be an indication for a relatively poor environment especially for deep burrowing earthworms. On a spot with frequent pool formation in winter (surface about $10 \mathrm{~cm}$ below average) already at a depth of $20 \mathrm{~cm}$ the number of small worm holes was very low and no large worm holes at all were observed.

Pool formation was observed in autumn and winter of the last few years but also after a heavy rain storm in the summer of 1975 in the night of June $23 /$ June 24 with $44 \mathrm{~mm}$ rain in less than 6 hours. The slower water intake on zero-tillage plots cannot be explained by an impermeable layer in the top soil. Air permeability of samples at field water content from a depth of $0-5$ and $5-10 \mathrm{~cm}$ taken one day before this rain storm occurred turned out to be fast to very fast for $0-5 \mathrm{~cm}$ and moderately fast to fast for $5-10 \mathrm{~cm}$. Air permeability at $\mathrm{pF} 2.0$ was moderately fast to very fast and slow to moderately fast, respectively. So the platy structure from $2-4 \mathrm{~cm}$ cannot be considered a serious barrier. After the rain storm the whole surface was slaked 
Table 5. The number of small $(\varnothing 2-4 \mathrm{~mm})$ and large $(\varnothing>4 \mathrm{~mm})$ worm holes per $\mathrm{m}^{2}$ of untilled soil (October 1975). Spot 1 and 2 on the main sampled plot (with maize in 1973) and spot 3 with temporary pool formation in winter of an adjacent plot.

\begin{tabular}{|c|c|c|c|c|c|c|}
\hline \multirow[t]{2}{*}{ Depth $(\mathrm{cm})$} & \multicolumn{2}{|c|}{ Spot 1} & \multicolumn{2}{|c|}{ Spot 2} & \multicolumn{2}{|c|}{ Spot 3} \\
\hline & 1* & $2 *$ & 1 & 2 & 1 & 2 \\
\hline 2 & 540 & 260 & 600 & 80 & 540 & 0 \\
\hline 10 & 620 & 180 & 400 & 40 & 120 & 0 \\
\hline 20 & 460 & 40 & 340 & 40 & 40 & 0 \\
\hline 30 & 160 & 20 & 220 & 0 & 0 & 0 \\
\hline
\end{tabular}

1: ø $2-4 \mathrm{~mm} ; 2: ø>4 \mathrm{~mm}$.

except where large shrinkage cracks were present. These cracks were nearly absent on the zero-tillage soil but were frequently observed on ploughed plots between two plough furrows. It is probable that the water ponded on the slaked soil and flowed horizontally to the nearest lowest place. Only when this was a wide crack water transport proceeded fast at first but slowed down thereafter because water had to be transported along smaller pores into the soil mass itself. Six hours after the end of the rain storm there was still water standing in some cracks on the lowest parts of the plowed plots (Fig. 9). Within the soil mass itself, especially within large aggregates, as could be observed, the soil was still pretty dry even 12 hours after the end of the rain storm. Water could be seen much longer on large parts of the zerotillage plots because vertical infiltration was slower in the absence of cracks. In the second place the buffering capacity is lower while air content at a certain suction is lower than after ploughing. On about half of the zero-tillage plot with maize (with a length of approximately $40 \mathrm{~cm}$ ) water ponded for more than 12 hours, on the lowest spots even more than 24 hours. Already a few hours after the end of the rain storm many dead worms (Fig. 10) - at some places more than $20 / \mathrm{m}^{2}-$ and

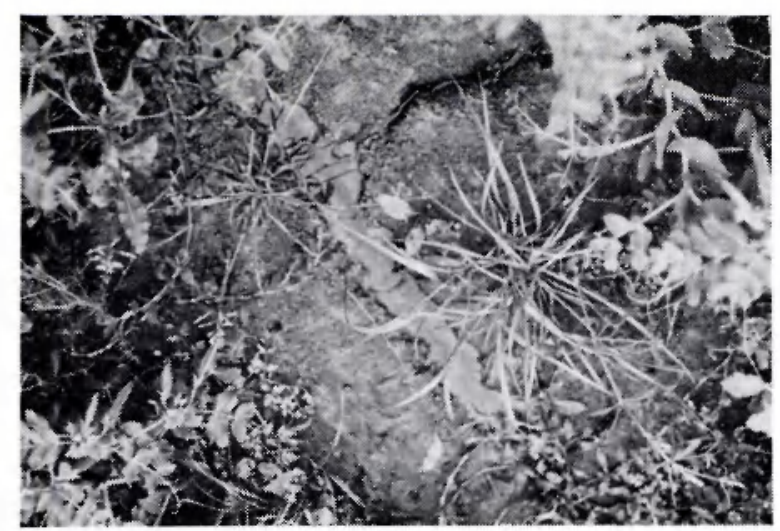

Neth. J. agric. Sci. 24 (1976)
Fig. 9. Six hours after the end of a heavy rain storm (June 1975) water was standing only in some cracks on the lowest parts of the ploughed plots. 


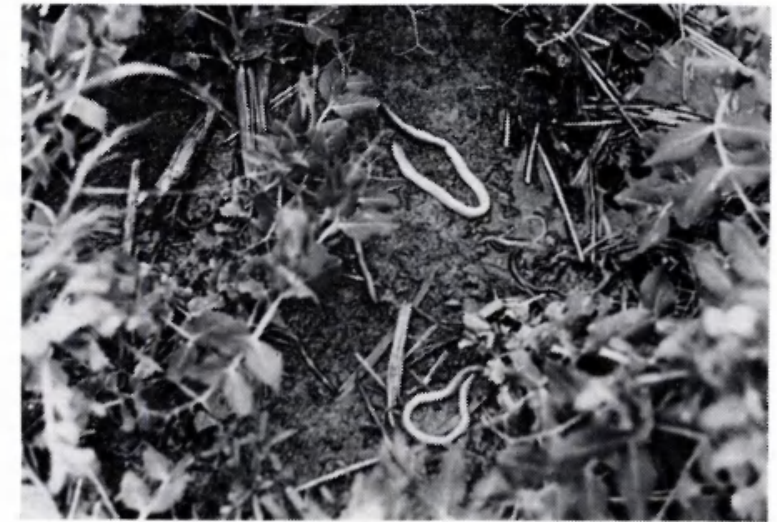

Fig. 10. A few hours after the end of a heavy rain storm (June 1975) many dead worms and many fresh worm holes were observed at the soil surface of the zero-tillage plots.

many fresh worm holes were observed at the soil surface. A lack of oxygen as might be supposed in large parts of the soil cannot be the only factor responsible. From own observations it appeared that the worm species prevailing on this experimental field (including juveniles and adults) survived in tap water $\left(10 \mathrm{~cm} \mathrm{high,} 20^{\circ} \mathrm{C}\right)$ for more than 3 days. Probably the movement of worms improved the oxygen supply by convection. Although there is no experimental proof, toxic gasses like $\mathrm{H}_{2} \mathrm{~S}$ might have killed some worms (D. Doeksen, 1975, personal communication); poisening by herbicides is less probable.

On plots with only 2 years of zero-tillage pool formation was on average less than on soil which was untilled for a longer period. It is clear that in agricultural practice zero-tillage is dangerous on this type of soil, since it introduces insecurities especially for crops sown in autumn like winter wheat. In the last two years a great deal of the winter wheat crop got lost in this way. This coincided with winters with almost no frost. Up till now there is no important experience with soil structure improvement of untilled soil in the Netherlands.

For conditions prevailing in the Netherlands there seem to be at least two soil texture ranges that are not very suited for zero-tillage. In the first place it appeared that soil structure on sandy soils is inadequate for root crops when tillage is not carried out. This was especially true for a loamy sand (van Ouwerkerk \& Boone, 1970) whereas compaction on sandy soils with a high organic matter content seems to be less critical. In the second place, on fine-textured soils sometimes aeration seems to be inadequate and in this case also small grains are damaged in some years. On the experimental field under consideration sometimes water content remained high on the untilled soil in the spring. As a consequence sowing was delayed more than on the normal ploughed plot (Bakermans, 1975, personal communication) which is in contrast with the normal observation on untilled soil (Baeumer \& Bakermans, 1973). 


\section{Acknowledgments}

We are indebted to Mr G. J. van de Waal for the preparation of the thin sections, to $\mathrm{Mr}$ Th. Pape and $\mathrm{Mr} \mathrm{Z}$. van Druuten for preparation of the photographs and to $\mathrm{Mr}$ B. Kroesbergen who developed the apparatus for the determination of the gas diffusion coefficient and made the drawings. We gratefully acknowledge the stimulating discussions with Prof. Ir. H. Kuipers. The hospitality offered by the Institute for Biological and Chemical Research on Field Crops and Herbage (IBS), Wageningen, on the experimental field in Randwijk has been appreciated very much.

\section{References}

Anonymous, 1961. Soil survey manual. Soil Survey Staff, USDA Handbook 18; 503 pp.

Bakermans, W. A. P., 1970. Crop husbandry on naturally compacted soils. Neth. J. agric. Sci. 18: 225-246.

Bakermans, W. A. P., 1972. Zero-tillage of arable crops. In: Annual Report 1972. Meded. Inst. biol. scheik. Onderz. LandbGewassen 470: 22-23.

Bakermans, W. A. P., F. R. Boone \& C. van Ouwerkerk, 1974. Nieuwe grondbewerkingssystemen. Ervaringen te Westmaas, $1968 \mathrm{t} / \mathrm{m}$ 1971. Bedrijfsontwikkeling 5 (7/8): 639-650.

Baeumer, K. \& W. A. P. Bakermans, 1973. Zero-tillage. Adv. Agron. 25: 77-123.

Bakker, J. W. \& A. P. Hidding, 1970. The influence of soil structure and air content on gas diffusion in soils. Neth. J. agric. Sci. 18: 37-48.

Boone, F. R., 1976. Flax growth in relation to artificial soil structures. (In preparation.)

Bouma, J., 1969. Microstructure and stability of two sandy loam soils with different soil management. Agric. Res. Rep. 724. Pudoc, Wageningen, 110 pp.

Brewer, R., 1964. Fabric and mineral analysis of soils. John Wiley, New York, $470 \mathrm{pp}$.

Ehlers, W., 1975. Observations on earthworm channels and infiltration on tilled and untilled loess soil. Soil Sci. 119 (3): 242-249.

Fleige, H. \& K. Baeumer, 1974. Effect of zero-tillage on organic carbon and total nitrogen content, and their distribution in different $\mathrm{N}$-fractions in loessical soils. Agro-Ecosystems 1: 19-29.

Jongerius, A., 1970. Some morphological aspects of regrouping phenomena in Dutch soils. Geoderma 4: 311-383.

Kmoch, H. G., 1961. Die Bestimmung der Luftdurchlässigkeit des Bodens und ihre Bedeutung für einige Ackerbauliche Probleme. Verlag Borntraeger, Berlin, $86 \mathrm{~S}$.

Kuipers, H., 1961. Water content at pF 2.0 as a characteristic in soil cultivation research in the Netherlands. Neth. J. agric. Sci. 9: 27-35.

Kuipers, H., 1968. Bemerkungen zu dem Zusammenhang zwisschen Bodendichte und Luft- und Wasserversorgung. Proceedings of the International Scientific Symposium, 22-24 June, 1966, Brno, Czechoslovakia.

Miedema, R., Th. Pape \& G. J. van de Waal, 1974. A method to impregnate wet soil samples, producing high-quality thin sections. Neth. J. agric. Sci. 22: 37-39.

Ouwerkerk, C. van \& F. R. Boone, 1970. Soil-physical aspects of zero-tillage experiments. Neth. J. agric. Sci. 18: 247-261.

Plas, L. van der \& A. C. Tobi, 1965. A chart for judging the reliability of point counting results. Am. J. Sci. 263: 87-90.

Schuylenborgh, J. van, S. Slager \& A. G. Jongmans, 1970. On soil genesis in temperate humid climate. VIII. The formation of a 'Udalfic' Eutrochrept. Neth. J. agric. Sci. 18: 207-214.

Slager, S., 1966. Morphological studies of some cultivated soils. Agric. Res. Rep. 670; 111 pp. 